\title{
Utility of late summer transient snowline migration rate on Taku Glacier, Alaska
}

\author{
M. Pelto \\ Nichols College, Dept. of Environmental Science, Nichols College Dudley, MA USA \\ Received: 31 December 2010 - Published in The Cryosphere Discuss.: 6 May 2011 \\ Revised: 19 October 2011 - Accepted: 17 November 2011 - Published: 15 December 2011
}

\begin{abstract}
On Taku Glacier, Alaska a combination of field observations of snow water equivalent (SWE) from snowpits and probing in the vicinity of the transient snowline (TSL) are used to quantify the mass balance gradient. The balance gradient derived from the TSL and SWE measured in snowpits at $1000 \mathrm{~m}$ from $1998-2010$ ranges from 2.6$3.8 \mathrm{~mm} \mathrm{~m}^{-1}$. Probing transects from $950 \mathrm{~m}-1100 \mathrm{~m}$ directly measure SWE and yield a slightly higher balance gradient of $3.3-3.8 \mathrm{~mm} \mathrm{~m}^{-1}$. The TSL on Taku Glacier is identified in MODIS and Landsat 4 and 7 Thematic Mapper images for 31 dates during the 2004-2010 period to assess the consistency of its rate of rise and reliability in assessing ablation for mass balance assessment. For example, in 2010, the TSL was $750 \mathrm{~m}$ on $28 \mathrm{July}, 800 \mathrm{~m}$ on 5 August, $875 \mathrm{~m}$ on $14 \mathrm{Au}-$ gust, $925 \mathrm{~m}$ on 30 August, and $975 \mathrm{~m}$ on 20 September. The mean observed probing balance gradient was $3.3 \mathrm{~mm} \mathrm{~m}^{-1}$, combined with the TSL rise of $3.7 \mathrm{~m} \mathrm{day}^{-1}$ yields an ablation rate of $12.2 \mathrm{~mm} \mathrm{day}^{-1}$ from mid-July to mid-Sept, 2010. The TSL rise in the region from $750-1100 \mathrm{~m}$ on Taku Glacier during eleven periods each covering more than 14 days during the ablation season indicates a mean TSL rise of $3.7 \mathrm{~m} \mathrm{day}^{-1}$, the rate of rise is relatively consistent ranging from 3.1 to $4.4 \mathrm{mday}^{-1}$. This rate is useful for ascertaining the final ELA if images or observations are not available near the end of the ablation season. The mean ablation from $750-1100 \mathrm{~m}$ during the July-September period determined from the TSL rise and the observed balance gradient is $11-13 \mathrm{~mm} \mathrm{day}^{-1}$ on Taku Glacier during the 2004-2010 period. The potential for providing an estimate of $b_{\mathrm{n}}$ from TSL observations late in the melt season from satellite images combined with the frequent availability of such images provides a means for efficient mass balance assessment in many years and on many glaciers.
\end{abstract}

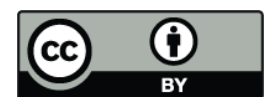

Correspondence to: $\mathrm{M}$. Pelto (mauri.pelto@nichols.edu)

\section{Introduction}

Ostrem (1975) first noted the utility of identifying the transient snow line (TSL) using remote sensing images in mass balance assessment. A temperate glacier consists of an ablation area and an accumulation area: with a maximum of four facies: an ice, wet snow, percolation and dry snow facies (Benson, 1962). Typical of temperate maritime glaciers, on Taku Glacier by late June in the vicinity of the TSL, there is only an ice and wet snow facies with the transition between the two describing the TSL (Ostrem, 1975). Late in the hydrologic year, the TSL approximates the glacier equilibrium line on most temperate glaciers including southeast Alaskan glaciers which lack superimposed ice (Hall et al., 1989). Ostrem (1975), Hall et al. (1989) and Williams et al. (1991) found that during the melt season the TSL is readily identifiable in satellite imagery. For the specific date of TSL observation annual mass balance at the TSL on temperate alpine glaciers is zero (Hock et al., 2007) and provide an important reference point for the balance gradient curve. Meier and Tangborn (1965) and Dyugerov and Meier (1999) noted that the balance gradient, the change in mass balance with elevation, for temperate glaciers varied little from year to year. Dyurgerov (1996) developed a method to compute a transient mass balance $\left(b_{\mathrm{nt}}\right)$ and the mass balance $\left(b_{\mathrm{n}}\right)$ at a particular time for a glacier, based on observation of the TSL, which was used to determine the transient accumulation area ratio (AAR) associated with each TSL and transient $b_{\mathrm{nt}}$ value. This relationship can be utilized to determine the annual mass balance if the relationship between transient $b_{\mathrm{nt}}$ and TSL is identical to the relationship between $b_{\mathrm{n}}$ and ELA over many years (Dyurgerov, 1996). The potential for providing an estimate of $b_{\mathrm{n}}$ from TSL observations late in the melt season from satellite images combined with the frequent availability of such images that can identify the TSL provides a means for efficient alpine glacier mass balance assessment in many years and on many glaciers.

Published by Copernicus Publications on behalf of the European Geosciences Union. 
Combining TSL observations with field snow depth measurements on Taku Glacier, Alaska allows examination of the consistency of the rate of TSL rise and assesses the accuracy of ablation determination. These two factors determine the potential for using satellite images TSL observations for assessing mass balance and the balance gradient. Prior to the availability of daily MODIS (Moderate Resolution Imaging Spectroradiometer) images the number of useful Landsat images for TSL observations was insufficient to provide several reliable TSL observations each year late in the ablation season. In 2009 there was no usable Landsat images after early August and in 2010 only one usable image during the entire field season. MODIS has a $250 \mathrm{~m}$ resolution, which limits its use to larger alpine glaciers and ice sheets for TSL identification and this aspect will be further discussed in the methods section.

\section{Study area}

Taku Glacier $\left(58.4^{\circ} \mathrm{N} 134.1^{\circ} \mathrm{W}\right)$ was selected because of the long mass balance record measured by the Juneau Icefield Research Program (JIRP) which extends from 1946-2010 (Pelto and Miller, 1990; Pelto et al., 2008). Taku Glacier is a temperate, maritime valley glacier in the Coast Mountains of Alaska. With an area of $671 \mathrm{~km}^{2}$, it is the principal outlet glacier of the Juneau Icefield (Fig. 1). The mean ELA during the 1998-2010 period is at $950 \mathrm{~m}$. In the region of the glacier from $750-1150 \mathrm{~m}$ surface slopes range from 1.1 to $2.1^{\circ}$. This region on the Taku Glacier encompasses $131 \mathrm{~km}^{2}$ and approximately $20 \%$ of the glacier.

Taku Glacier is noteworthy for its positive mass balance from 1946-1988, which resulted from the cessation of calving around 1950 (Pelto and Miller, 1990). The positive mass balance resulting from this dynamic change gives the glacier an unusually high AAR (accumulation area ratio: percentage of glacier in accumulation zone at end of hydrologic year) for a non-calving glacier and makes the glacier relatively insensitive to climate change (Miller and Pelto, 1990; Pelto et al, 2008; Criscitiello, et al., 2010). The positive mass balance is continuing to drive its advance (Pelto and Miller, 1990; Post and Motyka, 1995; Pelto et al., 2008), while all other outlet glaciers of the Juneau Icefield are retreating, and during a period when alpine glacier mass balance globally has been dominantly negative (Zemp et al., 2009).

JIRP has relied on applying consistent mass balance methods at standard measurement sites (Pelto and Miller, 1990; Miller and Pelto, 1999). On Taku Glacier the key annual measurements are: (1) 17 test pits at fixed locations ranging in elevation from $950 \mathrm{~m}$ to $1800 \mathrm{~m}$ directly measuring the snow water equivalent (SWE) through the entire snowpack profile, (2) ablation measurements at survey stakes along survey profiles, (3) observations of the TSL and ELA (Pelto and Miller, 1990; Pelto et al., 2008). LaChapelle (1956) first noted that the density of the snowpack is consistent and fixed

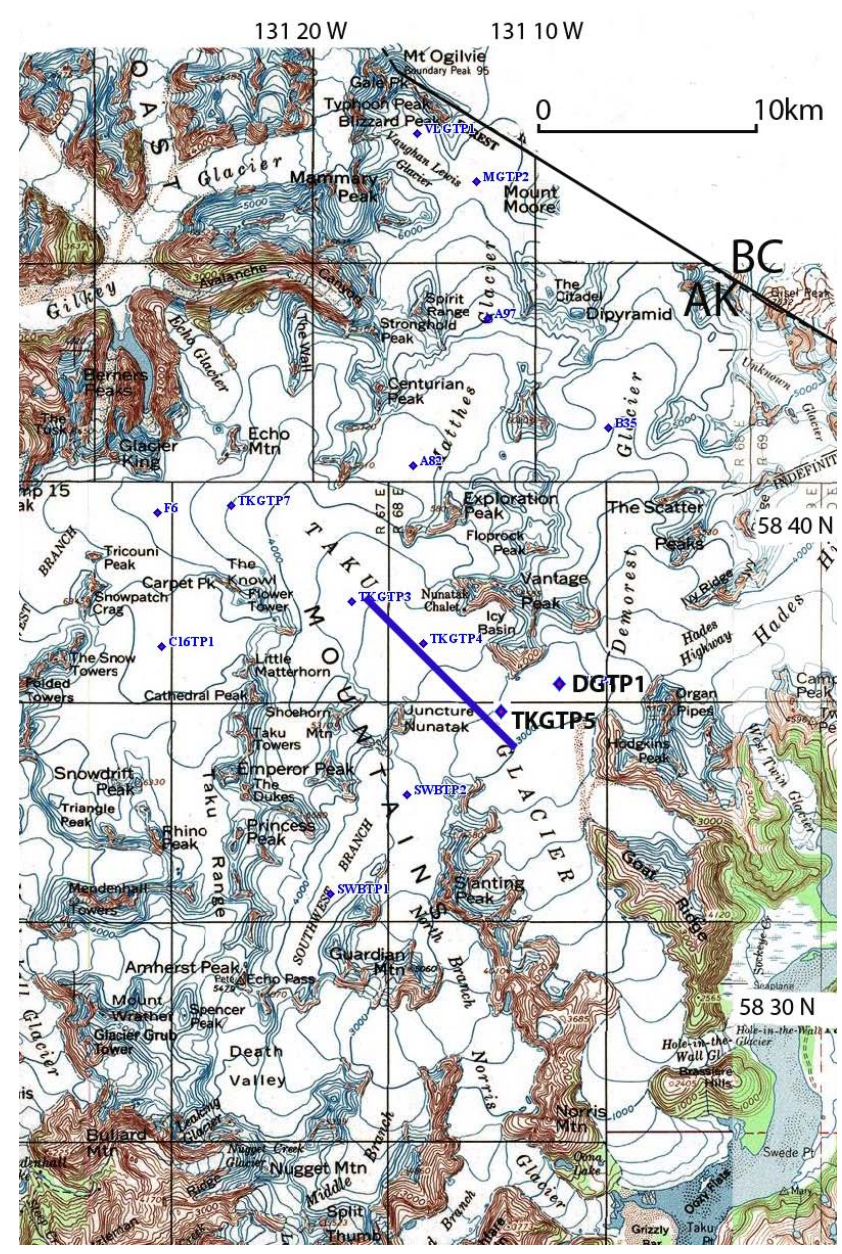

Fig. 1. Location map for Taku Glacier indicating the snowpit locations and probing transect noted. The Probing transect is the solid blue line. The two key snowpits TKGTP1 and DGTP1 are indicated in bold black, other snowpits are in blue.

$540-570 \mathrm{kgm}^{-3}$ after early July on the Taku Glacier (Pelto and Miller, 1990).

Measurements of retained accumulation in the snowpits are completed during late July and August and are adjusted to end of the balance year values based on the variations of the TSL, observed ablation and the measured balance gradient (Pelto and Miller, 1990; Miller and Pelto, 1999). Ablation during the field season is observed at survey stakes along survey lines where repeat surveys are completed and through migration of the TSL (Pelto and Miller, 1990; Pelto et al., 2008). Prior to the availability of consistent annual summer satellite imagery in 1984 the TSL was determined by field observations by JIRP in early July, late July, mid-August and in early September with this last observation assumed to be the ELA. From 1984-1997 remote sensing images supplemented the field observations. After 1998 remote sensing imagery has provided many of the TSL and ELA observations and since 2004 the majority. 
Table 1. Dates of transient snowline identification $(m)$ for Taku Glacier from Landsat 4-7 imagery and MODIS imagery (*).

\begin{tabular}{lrlr}
\hline Date & Taku TSL & Date & Taku TSL \\
\hline $15 / 07 / 2004$ & $\mathbf{8 5 0}$ & $03 / 07 / 2008$ & $\mathbf{4 0 0}$ \\
$16 / 08 / 2004$ & $\mathbf{9 5 0}$ & $22 / 07 / 2008$ & $\mathbf{5 5 0}$ \\
$01 / 09 / 2004$ & $\mathbf{1 0 3 0}$ & $05 / 08 / 2008^{*}$ & $\mathbf{7 5 0}$ \\
$07 / 06 / 2005$ & $\mathbf{4 7 5}$ & $19 / 08 / 2008$ & $\mathbf{8 0 0}$ \\
$10 / 08 / 2005$ & $\mathbf{8 7 0}$ & $26 / 09 / 08^{*}$ & $\mathbf{8 0 0}$ \\
$11 / 09 / 2005$ & $\mathbf{9 7 5}$ & $02 / 07 / 2009$ & $\mathbf{5 0 0}$ \\
$26 / 05 / 2006$ & $\mathbf{3 7 0}$ & $29 / 07 / 2009$ & $\mathbf{8 0 0}$ \\
$10 / 06 / 2006$ & $\mathbf{5 7 5}$ & $05 / 08 / 2009$ & $\mathbf{8 5 0}$ \\
$05 / 07 / 2006$ & $\mathbf{7 3 0}$ & $31 / 08 / 2009^{*}$ & $\mathbf{9 2 5}$ \\
$28 / 07 / 2006$ & $\mathbf{8 0 5}$ & $14 / 09 / 09^{*}$ & $\mathbf{9 5 0}$ \\
$14 / 09 / 2006$ & $\mathbf{9 8 0}$ & $08 / 07 / 2010^{*}$ & $\mathbf{5 8 0}$ \\
$15 / 07 / 2007$ & $\mathbf{5 5 0}$ & $05 / 08 / 2010^{*}$ & $\mathbf{8 1 0}$ \\
$25 / 07 / 2007 *$ & $\mathbf{6 7 5}$ & $14 / 08 / 2010^{*}$ & $\mathbf{8 7 5}$ \\
$16 / 08 / 2007$ & $\mathbf{8 7 5}$ & $29 / 08 / 2010$ & $\mathbf{9 1 5}$ \\
$02 / 09 / 2007$ & $\mathbf{9 3 0}$ & $20 / 09 / 2010^{*}$ & $\mathbf{9 7 5}$ \\
$25 / 07 / 2007 *$ & $\mathbf{6 7 5}$ & & \\
\hline
\end{tabular}

The Taku Glacier mass balance record has been confirmed by independent observation of glacier surface elevation change using the ongoing laser altimetry by the University of Alaska, Fairbanks (Echelmeyer et al., 1996), indicating a $B_{\mathrm{a}}$ of $-0.21 \mathrm{~m} \mathrm{a}^{-1}$ for the 1993-2007 period, compared to the JIRP mean $B_{\mathrm{a}}$ of $-0.16 \mathrm{ma}^{-1}$. A comparison of the surface elevation from the 2000 Shuttle Radar Topography Mission and a DEM derived from the 1948 USGS mapping indicates a mean $B_{\mathrm{a}}$ of $+0.45 \mathrm{~m} \mathrm{a}^{-1}$ versus the JIRP record of $+0.27 \mathrm{~m} \mathrm{a}^{-1}$ for the 1948-2000 period (Larsen et al., 2007).

\section{Methods}

For this study our goal is not further assessment of the overall mass balance of the glacier, but variations of mass balance during the ablation season near the TSL. Data from two snowpits (TKTP5 and DGTP1) near the ELA at $1000 \mathrm{~m}$ with consistent annual observations are used (Fig. 1). Three lines of evidence are used to identify the TSL, balance gradient and ablation rate. Remote sensing imagery is used to identify the TSL. Examination of available Landsat Thematic Mapper (TM) imagery from the USGS Globalization Viewer (http://glovis.usgs.gov/) identified 21 scenes from 2004-2010 where the TSL could be readily identified during the ablation season on Taku Glacier (Table 1). For Landsat (TM) imagery Taku Glacier falls in Path/Row 58/19, all images provided are RGB color composites, bands 5, 4, and 3 from the Landsat 7 (TM) and from Landsat 4-5 (TM), with a $2 \%$ linear stretch applied. The spatial resolution of $30 \mathrm{~m}$ combined with mean surface slopes of $1.6^{\circ}$ yields an error of less than $\pm 2 \mathrm{~m}$ in elevation for TSL.

To expand the coverage MODIS real time true color swath imagery from the Geographic Institute Network of Alaska (GINA-http://www.gina.alaska.edu/data/ gina-modis-images/) has been utilized on 10 occasions (Table 1). The MODIS imagery is from band 1 which has a resolution of $250 \mathrm{~m}$. With the average surface slope of $1.6^{\circ}$ this yields an error of less than $\pm 10 \mathrm{~m}$ in elevation for TSL. A comparison of a Landsat image and MODIS image from 29 July 2009 is provided (Fig. 2). It is evident that though some detail is lost the TSL position identified overall is not significantly different. A more detailed comparison better comparing the accuracy of MODIS for this will follow, but at this time there are not sufficient duplicate dates for Taku Glacier to allow for a quantitative assessment.

All images are overlain on a USGS DEM based on the 1948 aerial photography. A comparison of surface elevation from the 2000 Shuttle Radar Topography Mission and the 1948 USGS DEM indicates a surface change in the study area of 15-20m (Larsen et al., 2007). This agrees with the JIRP observed thickening in this region of $20 \mathrm{~m}$ (Pelto et al., 2008). In the study area from 2000-2009 no significant change in surface elevation has been observed (Pelto et al., 2008; Larsen et al., 2007). The slope and velocity of the glacier in this region has been remarkably consistent as well (Pelto et al, 2008), indicating a relatively homogenous change in surface elevation over the study reach. The elevation error resulting from using the USGS DEM is relatively consistent and a correction of $20 \mathrm{~m}$ is assessed to all TSL observations.

Probing transects in late July have been utilized to determine the balance gradient in more detail in the vicinity of the ELA. In 1998 (Mauri Pelto), 2004 and 2005 (Matt Beedle) and 2010 (Chris McNeil), as part of JIRP, measured the mass balance along transects from near the TSL at $900 \mathrm{~m}$ to $1150 \mathrm{~m}$ in late July using probing at a horizontal interval of $200 \mathrm{~m}$. Three measurements made within $25 \mathrm{~m}$ were averaged to determine the snowpack depth at each probing location. SWE is then determined from the snowpack depth and mean snow density observed in the snowpits along the probing transect in three locations.

At each test pit the SWE is directly identified along with the snowpack depth. SWE varied from $300 \mathrm{~mm}$ in 2003 to $1920 \mathrm{~mm}$ in 2000, with a mean of $1200 \mathrm{~mm}$ (Fig. 3). The mean difference between the two snowpits is $65 \mathrm{~mm}$. The two snowpits, TKTP5 and DGTP1, have been completed within a few days of 20 July each year since 1998. The difference in SWE between the snowpits and TSL, where SWE is by definition zero, and the difference in elevation between the TSL and the snowpits provides a direct measure of the balance gradient in late July. For the average year on 20 July SWE is $1200 \mathrm{~mm}$ at the testpits at $1000 \mathrm{~m}$ and $0 \mathrm{~mm}$ at the TSL. If the TSL is $800 \mathrm{~m}$ on 20 July than the balance

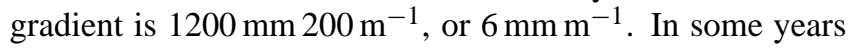
the TSL is lower than region where probing transects reach, and the balance gradient is not as well established from field observations at elevations below $800 \mathrm{~m}$. 


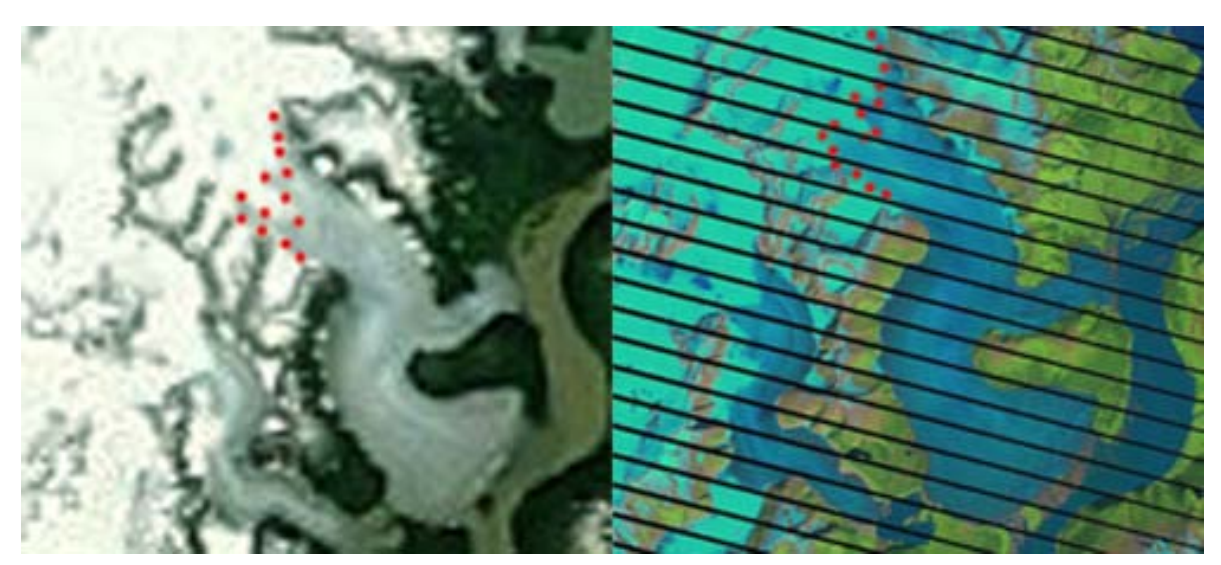

Fig. 2. Side by MODIS and Landsat 7 image from 292009 is provided with the TSL noted with red dots on each image.

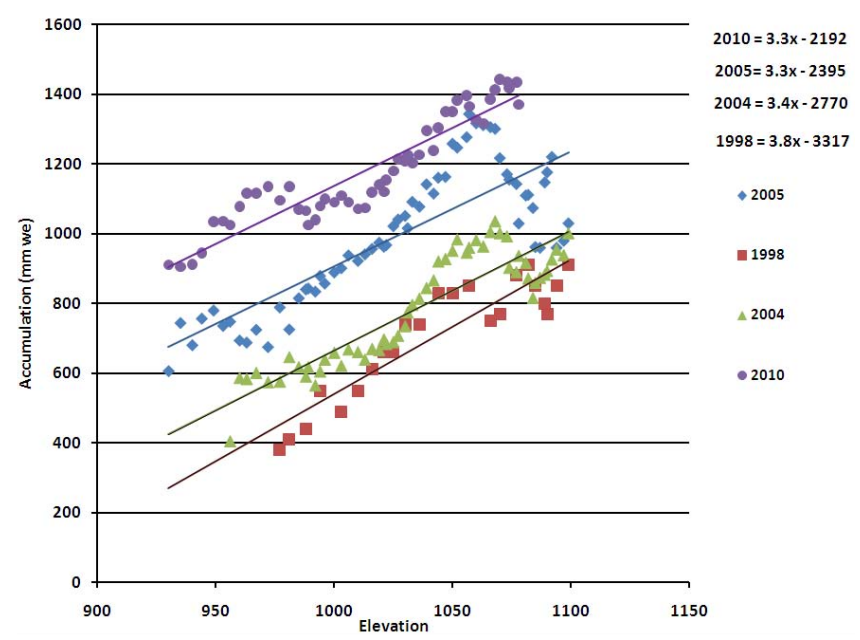

Fig. 3. TKTP5 and DGTP1 testpit SWE 1998-2010 at $1000 \mathrm{~m}$ on Taku Glacier.

\subsection{Balance gradient observations near the TSL}

Probing transects conducted in 1998, 2004, 2005 and 2010 utilize the same measurement transect to assess SWE at $200 \mathrm{~m}$ intervals from near the TSL during late July to $1150 \mathrm{~m}$. This directly identifies the mass balance gradient at this elevation for late July (Fig. 4). The balance gradient determined from probing above the TSL ranges from $3.3-3.8 \mathrm{~mm} \mathrm{~m}^{-1}$, with a mean of $3.5 \mathrm{~mm} \mathrm{~m}^{-1}$. The balance gradient has been consistent on Taku Glacier for each year observed regardless of the respective mass balance or ELA for that year (Fig. 4).

The SWE at the two test pits provides a direct measure of the balance gradient from the TSL to the snowpits at $1000 \mathrm{~m}$ in late July (Fig. 5). The Taku Glacier balance gradient from the TSL to the snowpits at $1000 \mathrm{~m}$ from 1998 to 2009 ranged from 2.8 to $3.7 \mathrm{~mm} \mathrm{~m}^{-1}$, with a mean of $3.3 \mathrm{~mm} \mathrm{~m}^{-1}$. The gradient is slightly lower than the mean $3.5 \mathrm{~mm} \mathrm{~m}^{-1} \mathrm{ob}-$ served from probing above the TSL. The 2003 balance gra-

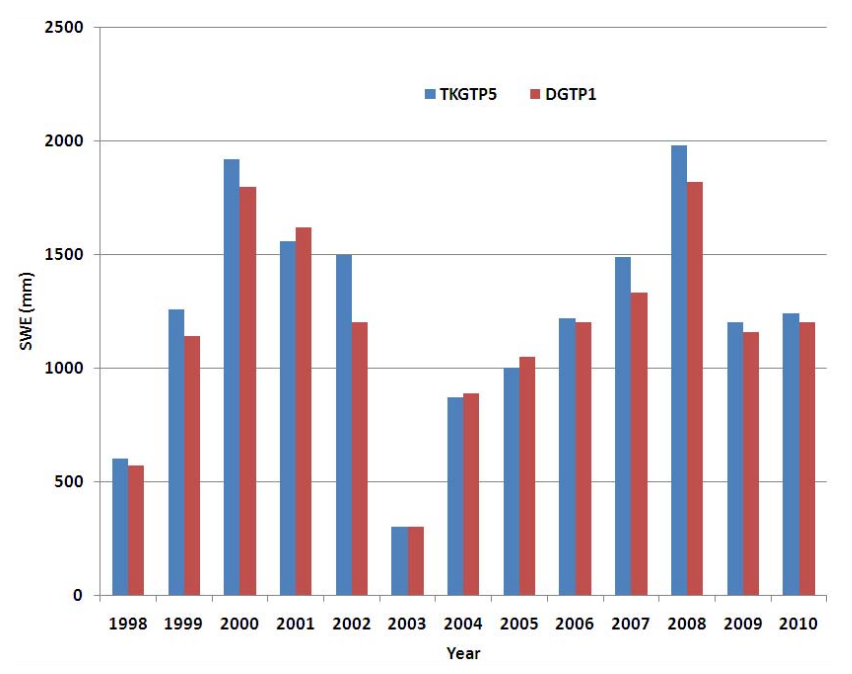

Fig. 4. Juneau Icefield annual snow pit measurements near the ELA on Taku Glacier from 1998-2010 in mm of SWE.

dient was not determined as the TSL was too close to the snowpits on 20 July for a reliable gradient to be determined.

The TSL is identified in Landsat and MODIS imagery by overlaying the images on the USGS DEM. For years with multiple images, the rate of rise of the TSL is determined. This rate of rise is only calculated for periods of longer than 15 days. For example in 2006 the ELA was identified in five Landsat images on Taku Glacier. The ELA rose from $370 \mathrm{~m}$ on May 26, to $575 \mathrm{~m}$ on 10 June, $730 \mathrm{~m}$ on 5 July , $800 \mathrm{~m}$ on 29 July, and finally $980 \mathrm{~m}$ on 15 September (Fig. 6). For Taku Glacier there are sixteen periods since 2004 where the TSL was observed at dates separated by more than 14 days (Table 2). The TSL rise ranged from 3.1 to $4.4 \mathrm{~m} \mathrm{day}^{-1}$. Mean rise of the TSL for 16 periods averages $3.7 \mathrm{~m} \mathrm{day}^{-1}$ during the July-September period, for the elevation range between 750-1100 $\mathrm{m}$ (Table 2). At shorter intervals the elevation difference is too small to avoid large errors in balance gradient 
Table 2. Periods between TSL observations separated by at least 14 days. For each period the rate of rise is determined. The group of observations for lower elevations is for periods where the TSL on the start date was below $750 \mathrm{~m}$.

\begin{tabular}{|c|c|c|c|c|}
\hline Start Date & End Date & Days & $\begin{array}{l}\text { Rise } \\
(\mathrm{m})\end{array}$ & $\begin{array}{c}\text { Rate of } \\
\text { Rise }\end{array}$ \\
\hline $15 / 07 / 2004$ & $1 / 09 / 2004$ & 47 & 180 & 3.83 \\
\hline $15 / 07 / 2004$ & $16 / 08 / 2004$ & 32 & 100 & 3.13 \\
\hline $10 / 08 / 2005$ & $11 / 09 / 2005$ & 31 & 125 & 4.03 \\
\hline 05/07/2006 & $14 / 09 / 2006$ & 70 & 250 & 3.57 \\
\hline 05/07/2006 & $28 / 07 / 2006$ & 23 & 75 & 3.07 \\
\hline $16 / 08 / 2007$ & $02 / 09 / 2007$ & 16 & 55 & 3.44 \\
\hline 08/05/2008 & $19 / 08 / 2008$ & 14 & 50 & 3.57 \\
\hline 29/07/2009 & $31 / 08 / 2009$ & 33 & 125 & 3.79 \\
\hline 29/07/2009 & $14 / 09 / 2009$ & 46 & 150 & 3.26 \\
\hline 05/08/2010 & $29 / 08 / 2010$ & 24 & 105 & 4.38 \\
\hline 05/08/2010 & $20 / 09 / 2010$ & 45 & 165 & 3.68 \\
\hline \multicolumn{4}{|c|}{ Mean } & 3.65 \\
\hline Lower & Elevations & & & \\
\hline $10 / 06 / 2006$ & 05/07/2006 & 25 & 180 & 7.20 \\
\hline $25 / 07 / 2007$ & 02/09/2007 & 38 & 275 & 7.24 \\
\hline 03/07/2008 & $8 / 5 / 2008$ & 33 & 250 & 7.58 \\
\hline 02/07/2009 & 29/07/2009 & 27 & 300 & 11.11 \\
\hline 08/07/2010 & 05/08/2010 & 27 & 170 & 6.30 \\
\hline
\end{tabular}

assessment. As evidenced in Table 2 earlier in the summer and or at lower elevations we lack the field data to corroborate the balance gradient, and the rate of TSL rise is markedly faster. For the five periods for elevations from $450-800 \mathrm{~m}$ the mean rate of rise was $7.9 \mathrm{~m} \mathrm{day}^{-1}$.

\subsection{Ablation determination from TSL observations and the balance gradient}

Ablation at the TSL is the product of the observed balance gradient and the TSL rate of rise. In 2006, the TSL rose from $370 \mathrm{~m}$ on 26 May, to $575 \mathrm{~m}$ on 10 June, $730 \mathrm{~m}$ on 5 July, $800 \mathrm{~m}$ on 29 July, and finally $980 \mathrm{~m}$ on 14 September (Fig. 5). The TSL rate of rise was $3.6 \mathrm{~m} \mathrm{day}^{-1}$ from 5 July 2006 to 14 September 2006. The balance gradient from snowpit data was $3.0 \mathrm{~mm} \mathrm{~m}^{-1}$ and from probing was $3.5 \mathrm{~mm} \mathrm{~m}^{-1}$. For 2006 the mean ablation rate at the TSL from 5 July to 14 September was $10.8 \mathrm{~mm} \mathrm{day}^{-1}$ from the snowpit balance gradient and $12.6 \mathrm{~mm} \mathrm{~m}^{-1}$ from the probing balance gradient. In 2010, the TSL rose from $750 \mathrm{~m}$ on 29 July, to $810 \mathrm{~m}$ on 5 August, $875 \mathrm{~m}$ on 14 August, $925 \mathrm{~m}$ on 30 August, and $975 \mathrm{~m}$ on 20 September (Fig. 6). The mean observed probing balance gradient was $3.3 \mathrm{~mm} \mathrm{~m}^{-1}$ and TSL rise was $3.7 \mathrm{~m} \mathrm{day}^{-1}$, yielding an ablation rate of $12.2 \mathrm{~mm} \mathrm{day}^{-1}$ on Taku Glacier from 28 July to 20 September 2010.

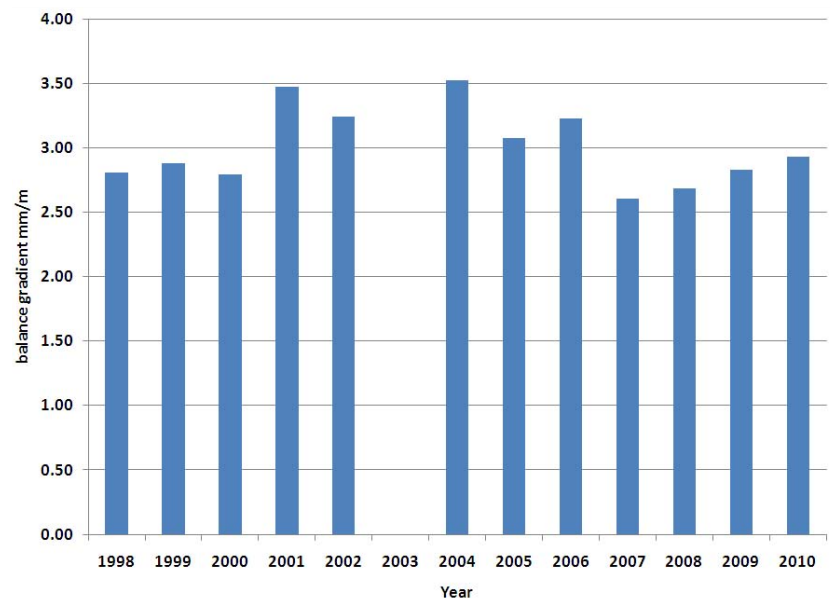

Fig. 5. Balance gradient on Taku Glacier between the snowpits and the transient snowline, based on snowpit data 1998-2010, except 2003 when the TSL was nearly at the snowpits.

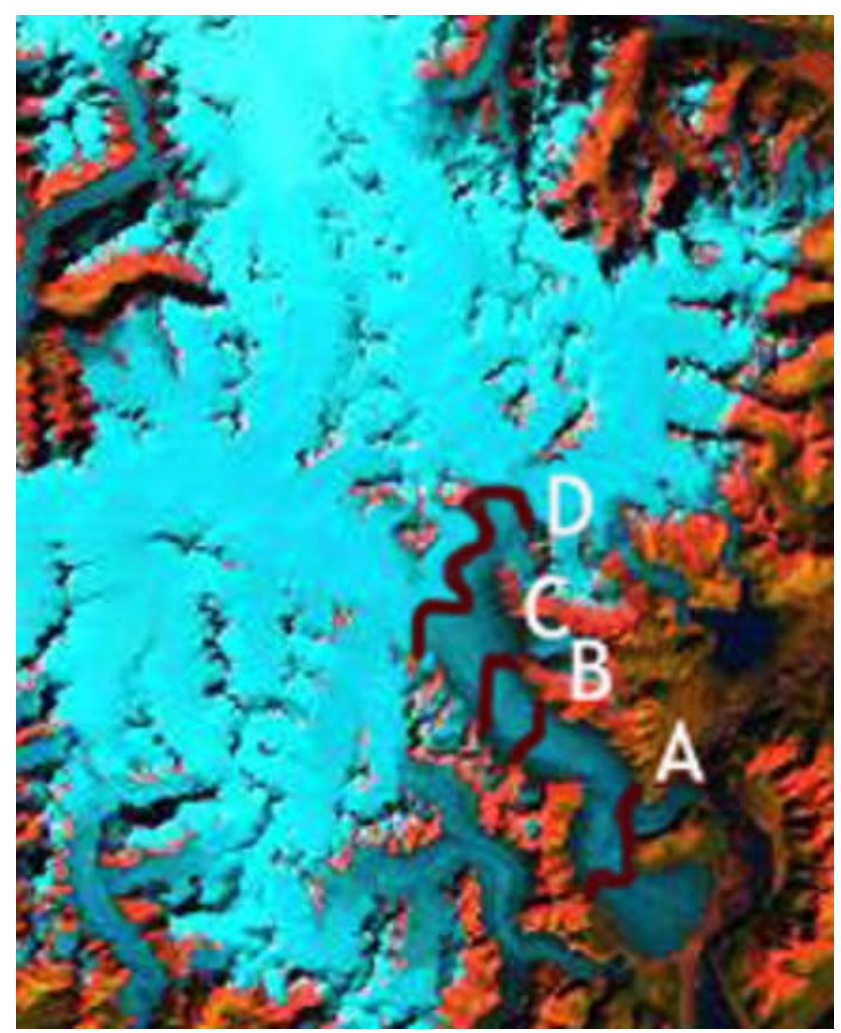

Fig. 6. TSL identification on Taku Glacier in 2006 Landsat image from 14 Semptember 2006. A=26 May 2006, B=5 July 2006, C=28 July 2006, D = 14 September 2006.

Mean daily ablation at the TSL can be determined from the rate of rise of the TSL and the balance gradient. Given the mean observed balance gradient near the TSL when it is between 750 and $1000 \mathrm{~m}$ on Taku Glacier is $3.5 \mathrm{~mm} \mathrm{~m}^{-1}$ from probing and $3.0 \mathrm{~mm} \mathrm{~m}^{-1}$ from snowpits, and daily TSL 
rise is $3.7 \mathrm{~m} \mathrm{day}^{-1}$, then the computed mean daily ablation is $11-13 \mathrm{~mm}$ water equivalent for the July-September period in the vicinity of the ELA. This illustrates the usefulness of the shift in position of the TSL for assessing ablation. Variations in the TSL through the course of the melt season identify ablation in the vicinity of the TSL and near the end of the ablation season in the vicinity of the ELA (Miller and Pelto, 1999). This application of the TSL to glacier mass balance depends on the calibration of the TSL to ablation for specific regions on specific glaciers. The consistency of the rate of rise of TSL on Taku Glacier from 750-1050 m over periods of several weeks or more suggests it can be reliably used in conjunction with a known balance gradient to assess mass balance characteristics near the ELA.

A further potential value is comparison of the rate of rise of the TSL on Taku Glacier to that of other nearby glaciers. The ratio of the rise in TSL on Taku Glacier to a nearby glacier in combination with the known balance gradient on the, benchmark, Taku Glacier would allow derivation of the balance gradient on the nearby glacier. A local glacier would have to be observed over simultaneous intervals and be in close enough proximity to the benchmark glacier toexperience the same climate conditions at the TSL. The MODIS imagery used for Taku Glacier typically had limited cloud cover across much of the Juneau Icefield, Stikine Icefield and Glacier Bay region. The daily availability of the MODIS images would provide ample simultaneous observations of the TSL on glaciers within this region.

\section{Conclusions}

Multiple observations of the TSL during the course of several melt seasons allowed determination of the consistency of the rate of rise in the TSL. If there is consistency in the rate and pattern of TSL rise then multiple TSL observations in the same melt season can provide a measure of ablation that can be quantified if the balance gradient of the glacier in the area of the TSL is known. On Taku Glacier the rate of TSL rise was consistent at $3.7 \mathrm{~m}$ day $^{-1} \pm 15 \%$. Due to the availability of satellite imagery from Landsat TM and MODIS the TSL has been identified late in the ablation season on Taku Glacier in each of the past $7 \mathrm{yr}$. On Taku Glacier the balance gradient assessed annually in the field using probing transects is $3.5 \mathrm{~mm} \mathrm{~m}^{-1}$ compared to $3.0 \mathrm{~mm} \mathrm{~m}^{-1}$ from snowpit measurements. This combined with the observed rate of TSL rise of $3.7 \mathrm{~m} \mathrm{day}^{-1}$ yields a mean daily ablation rate in the latter half of the ablation season of $11-13 \mathrm{~mm} \mathrm{day}^{-1}$. Multiple observations of TSL during a single balance year provide a means to better establish annual balance-ELA relationship, the balance gradient of a glacier and ablation near the TSL during the period of observation. The existence of imagery allowing frequent TSL observation and local balance gradient observations raises the possibility of extending TSL ob- servations to other glaciers on the Juneau Icefield for annual balance assessment or balance gradient determination.

Acknowledgements. The dedication of two individuals to the study of Alaskan glaciers led to the development of two data sets that are invaluable for assessing mass balance of Alaskan glacier over the last $50 \mathrm{yr}$, Keith Echelmeyer, University of Alaska, Fairbanks and Maynard Miller, University of Idaho. The commitment of Scott McGee, Matt Beedle and Chris McNeil in coordinating and replicating the 1998 probing profiles was also essential.

Edited by: A. Klein

\section{References}

Benson, C. S.: Stratigraphic studies in the snow and firn of Greenland ice sheet, CRREL (SIPRE) Res. Rpt., 70, 93 pp., 1962.

Criscitiello A., Kelly M., and Tremblay B.: The Response of Taku and Lemon Creek Glaciers to Climate, Arctic, Antarctic, and Alpine Res., 42, 34-44, 2010.

Dyurgerov M.: Substitution of long term mass balance data by measurements of one summer, Gletscherkd. Glazialgeol., 32, 177184, 1996.

Dyurgerov, M. B. and Meier, M. F.: Analysis of winter and summer glacier mass balances, Geogr. Ann., 81, 541-554, 1999.

Echelmeyer K. A., Harrison W. D., Larsen C. F., Sapiano J., Mitchell J. E., Demallie J., Rabus B., Adalgeirsdöttir G., and Sombardier L.: Airborne surface profiling of glaciers: a case study in Alaska, J. Glaciol, 42, 538-547, 1996.

Hall D. K., Chang A. T. C., Foster J. L., Benson C. S., and Kovalick W. M.: Comparison of in situ and Landsat derived reflectance of Alaskan glaciers, Remote Sens. Environ., 28, 23-31, 1989.

Hock, R., Koostra, D., and Reijmeer, C.: Deriving glacier mass balance from accumulation area ratio on Storglaciären, Sweden, in: Glacier Mass Balance Changes and Meltwater Discharge, IAHS 318, 163-170, 2007.

Larsen, C. F., Motyka, R. J., Arendt, A. A., Echelmeyer, K. A., and Geissler, P. E.: Glacier changes in southeast Alaska and northwest British Columbia and contribution to sea level rise, J. Geophys. Res., 112, F01007, doi:10.1029/2006JF000586, 2007.

Meier, M. F. and Tangborn, W.V.: Net budget and flow of South Cascade Glacier, Washington, J. Glaciol., 5, 547-566, 1965.

Miller M. M. and Pelto M.: Mass balance measurements on the Lemon Creek Glacier, Juneau Icefield, AK 1953-1998, Geografiska Annaler, 81, 671-681, 1999.

Østrem G.: ERTS data in glaciology - an effort to monitor glacier mass balance from satellite imagery, J. Glaciol., 15, 403-15, 1975.

Pelto M. and Miller M. M.: Mass Balance of the Taku Glacier, Alaska from 1946 to 1986, Northwest Science, 64, 121-130, 1990.

Pelto, M. S., Miller, M. M., Adema, G. W., Beedle, M. J., McGee, S. R., Sprenke, K. F., and Lang, M.: The equilibrium flow and mass balance of the Taku Glacier, Alaska 1950-2006, The Cryosphere, 2, 147-157, doi:10.5194/tc-2-147-2008, 2008.

Post, A. and Motyka, R.: Taku and Le Conte Glaciers, Alaska: Calving speed control of late-Holocene asynchrounous advances and retreats, Phys. Geogr., 16, 59-82, 1995. 
Williams R. S., Hall, D. K., and Benson C. S.: Analysis of glacier facies using satellite Techniques, J. Glaciol, 37, 120-128, 1991.
Zemp, M., Hoelzle, M., and Haeberli, M.: Six decades of glacier mass-balance observations: a review of the worldwide monitoring network, Annals Glaciol., 50, 101-111, 2009. 